\title{
Sandhoff Disease
}

National Cancer Institute

\section{Source}

National Cancer Institute. Sandhoff Disease. NCI Thesaurus. Code C85052.

An autosomal recessive inherited lysosomal storage disorder caused by mutations in the HEXB gene. It is characterized by deficiency of the enzyme hexosaminidase, resulting in the accumulation of gangiosides in the central nervous system and other body tissues. Signs and symptoms include progressive motor and mental deterioration, early blindness, macrocephaly, seizures, and hepatosplenomegaly. 